\title{
The Impact of COVID-19 Pandemic on Treatment, Follow- up and Behavioral Characteristics of Chronic Viral Hepatitis Patients
}

\section{COVID-19 Pandemisinin Kronik Viral Hepatit Hastalarının Tedavisi, Takibi ve Davranıș Özellikleri Üzerindeki Etkisi}

\author{
(1) Elif M. Sarıcaoğlu1, (1) Bircan Kayaaslan², (1) Rahmet Güner² \\ ${ }^{1}$ Ankara City Hospital, Clinic of Infectious Diseases and Clinical Microbiology, Ankara, Turkey \\ ${ }^{2}$ Ankara Yıldırım Beyazıt University, Ankara City Hospital, Clinic of Infectious Diseases and Clinical Microbiology, Ankara, Turkey
}

\begin{abstract}
Objectives: It has been not yet fully understood whether chronic liver diseases may be considered as risk factors for critical course of Coronavirus disease-2019 (COVID-19). Considering the importance of managing with COVID-19, we aimed to investigate the impact of the COVID-19 pandemic on treatment, follow-up and behavioral characteristics of chronic viral hepatitis $(\mathrm{CVH})$ patients.

Materials and Methods: Patients followed-up in our clinic with diagnosis of chronic hepatitis $\mathrm{B}$ or $\mathrm{C}$ were screened retrospectively and a total 213 adults included in the study. We performed a telephone survey with patients.

Results: The mean age of participants was $49.9 \pm 13.4$ years. Of the participants, $62 \%$ were male. Totally $75(35.2 \%)$ patients disrupted their follow-up visits due to COVID-19 pandemic. The only risk factor for disruption in follow-up was found as anxiety. The vast majority of CVH patients paid attention to prevention measures for COVID-19. Conclusion: We can say that CVH patients' awareness about COVID-19 and application of control measures were well enough. Continuity of treatment can be provided in patients with chronic illness during crisis period with informing patients in a way not to cause anxiety and efficient implementations in healthcare system. Keywords: Anxiety, chronic viral hepatitis, COVID-19
\end{abstract}

\section{ÖZ}

Amaç: Kronik karaciğer hastalıklarının Koronavirüs hastalığı-2019'un (COVID-19) kritik seyri için bir risk faktörü olup olmadığı henüz net olarak anlaşılamamıştır. COVID-19 ile mücadelenin önemi göz önünde bulundurularak, COVID-19 pandemisinin KVH hastalarının tedavi, takip ve davranış özellikleri üzerindeki etkisinin araştırıması amaçlanmıştır.

Gereç ve Yöntemler: Kronik hepatit B veya C tanıları ile kliniğimizde takip edilen hastalar retrospektif olarak taranmış ve toplam 213 erişkin hasta çalışmaya dahil edilmiştir. Hastalar ile telefon görüşmesi yapılarak anket gerçekleştirilmiştir.

Bulgular: Hastaların ortalama yaşı $49,9 \pm 13,4^{\prime}$ tür. Katılımcıların \%62'si erkektir. COVID-19 pandemisi nedeni ile toplam 75 (\%35,2) hasta takip vizitlerini aksatmıştır. Takibin aksatımasındaki tek risk faktörü anksiyete bulunmuştur. KVH hastalarının büyük çoğunluğu COVID-19'a yönelik korunma önlemlerine dikkat etmektedir.

Sonuç: KVH hastalarının COVID-19 farkındalıklarının ve kontrol önlemlerine uyumlarının oldukça iyi olduğu görülmüştür. Kriz dönemlerinde anksiyeteye neden olmayacak şekilde hastaların bilgilendirilmesi ve sağlık bakım sisteminde etkili uygulamalar sayesinde kronik hastalığı olan kişilerin tedavilerinin devamlılı̆ı sağlanabilir.

Anahtar Kelimeler: Anksiyete, kronik viral hepatit, COVID-19

Sarıcaoğlu EM, Kayaaslan B, Güner R. The Impact of COVID-19 Pandemic on Treatment, Follow-up and Behavioral Characteristics of Chronic Viral Hepatitis Patients. Viral Hepat J. 2020;26:98-103. 


\section{Introduction}

At the end of 2019, an outbreak of atypical pneumonia with an unknown etiology appeared in Wuhan, Hubei Province, China (1). The disease caused by novel coronavirus, Severe Acute Respiratory Syndrome Coronavirus-2 (SARS-CoV-2), has been officially named as the Coronavirus disease-2019 (COVID-19) by World Health Organization (WHO). The outbreak has been spread rapidly all over the world and became a major public health problem (2). WHO declared the COVID-19 outbreak as a pandemic on March 11, 2020 and Europe was declared as a new epicenter of outbreak on March 14, 2020 (3,4). The first COVID-19 case was reported in Turkey on March 11, 2020 (5). Numerous measures and policy have been implemented as a response to COVID-19 outbreak in our country (4).

Older patients and those with pre-existing comorbidities have been defined as risk groups for severe course of COVID-19 (6). A cohort study enrolling 1099 COVID-19 patients in China showed that $21(2.1 \%)$ patients had pre-existing chronic hepatitis B (7). Recently, a small case series consisted of three patients with confirmed COVID-19 and decompensated cirrhosis (one due to chronic hepatitis B) were published, they have call attention to that decompensated cirrhosis may be a risk factor for critical course of COVID-19 patients (8). It has been not yet fully understood whether chronic liver diseases may be considered as risk factors for COVID19 infection (6). During COVID-19 pandemic, it is essential to understand how the people have been coping with such a major threat on health. (1). There are no published data regarding the impact of COVID-19 infection on patients with chronic viral hepatitis $(\mathrm{CVH})$ in current reports. Our study aimed to investigate the impact of the COVID-19 pandemic on treatment, follow-up and behavioral characteristics of chronic hepatitis patients.

\section{Materials and Methods}

\section{Participants}

This study is a cross-sectional study conducted as a telephone questionnaire between 5 June 2020 and 8 June 2020. Adults older than 18 years who had been followed-up with the diagnosis of chronic hepatitis $\mathrm{B}$ or $\mathrm{C}$ in our clinic were screened retrospectively and had agreed to participate in this study were included. Any monetary rewards were not given participants for completing the survey.

The study protocol and procedures of informed consent were approved by Ankara City Hospital Ethical Committee (approval number: E1/724/2020, date: 04/06/2020). Participants were asked if they accept participating to the study at the beginning of the questionnaire and an informed consent was provided by answering a yes-no question.

\section{Survey}

The telephone survey consisted of four parts with 25 questions about demographics features, treatment and follow-up of $\mathrm{CVH}$, anxiety and risk assessment of patients about COVID-19 and behavioral changes of participants after COVID-19 pandemic. Prior to starting to questionnaire, participants were informed that participation was voluntary and they could stop at any time.

The first part of survey included basic demographic variables including age, gender, education, occupation, and place of current residence, comorbidities and medications. The second part consisted of the questions regarding if there is a break on the follow-up and/or treatment of CVH due to COVID-19 pandemic. The third part involved how participants perceive their own risk category for COVID-19 infection. In this part, additional questions were also asked about whether they were admitted to hospital and/or whether any investigation was made on preliminary diagnosis of COVID-19. The last part included nine questions asked to determine change in behavioral characteristics of patients after COVID-19 pandemic. They were asked whether if they made any changes daily routine behaviors such as avoiding going to out, using the public transport, staying away from crowded areas, meeting with relatives and friends, preferring internet shopping instead of markets, nutritional habits.

\section{Statistical Analysis}

Statistical analysis was performed by using SPSS software version 18.0. The results of descriptive statistics were reported as mean \pm standard deviation for variables with normal distribution and median (minimum-maximum) for variables without normal distribution. Categorical data were reported as frequencies and percentages. Chi-square test was used to assess if there was a significant association between categorical variables. Student's t-tests was used to determine differences between numerical values.

\section{Results}

A total 213 participants were included into the study (Table 1). The mean age of participants was $49.9 \pm 13.4$ years, and $50.7 \%$ were over 50 years of age. Of the participants, $62 \%$ were male and $46.9 \%$ had higher level of education. Of the patients, 35.6\% had at least one comorbidity and the most common comorbidities were hypertension and diabetes mellitus. Duration of $\mathrm{CVH} B$ and C were $12.6 \pm 6.08$ and $10.7 \pm 4.75$ years, respectively. One third of chronic hepatitis $B$ patients received tenofovir disoproxil fumarate or entecavir treatment. All of the chronic hepatitis $C$ patients had completed their antiviral treatment before COVID-19 pandemic.

While treatment interruption was seen in only three $\mathrm{CVH}$ patients, totally 75 (35.2\%) patients disrupted their follow-up visits due to COVID-19 pandemic. The most common reason was the afraid of admission to hospital (-21.1\%). In addition, 14 patients voluntarily disrupted their outpatient follow-up for reasons other than COVID-19. All causes of follow-up disruption were listed in Table 2. The investigated risk factors for follow-up disruption were showed in Table 3. The only statistically significant risk factor which negatively affect the follow-up in $\mathrm{CVH}$ patients was found as anxiety about being at higher risk for COVID-19 due to hepatitis $(\mathrm{p}=0.002)$.

Fifty-three (24.9\%) CVH patients were anxious for being at higher risk for COVID-19 due to hepatitis disease. Causes of their anxiety were the thought of carrying a higher risk for acquiring of the infection or having more severe forms of COVID-19 infections due to hepatitis $(14.6 \%)$, thought of being immunosuppressive due to hepatitis (13.6\%) and fear of having more side effects of COVID-19 drugs during treatment due to hepatitis (2.3\%). Baseline characteristics of patients with and without anxiety about COVID- 
19 were similar according to age, education level, prescence of any comorbidity, type of hepatitis and duration of illness. The only statistically significant factor that caused anxiety was found as gender $(\mathrm{p}=0.010)$.

Only $3(1.4 \%)$ patients applied to hospital with suspicion of COVID-19. All of them had a negative COVID-19 polymerase chain reaction test and normal thorax computerized tomography. Of the patients, 7 (3.3\%) had a person in own family or close social environment who have been infected with COVID-19. None of the $\mathrm{CVH}$ patients were diagnosed with COVID-19.

\begin{tabular}{|c|c|}
\hline Total participants, $\mathbf{n}$ & 213 \\
\hline \multicolumn{2}{|l|}{ Age, years, (n, \%) } \\
\hline $18-30$ & $12(5.6)$ \\
\hline $31-40$ & $54(25.4)$ \\
\hline $41-50$ & $39(18.3)$ \\
\hline$>50$ & $108(50.7)$ \\
\hline Male, (n, \%) & $132(62)$ \\
\hline \multicolumn{2}{|l|}{ Education (n, \%) } \\
\hline Illiterate & $11(5.16)$ \\
\hline Primary education & $82(38.5)$ \\
\hline Secondary school & $20(9.4)$ \\
\hline High school & $49(23)$ \\
\hline University & $51(23.9)$ \\
\hline \multicolumn{2}{|l|}{ Occupation (n, \%) } \\
\hline Working & $143(67.1)$ \\
\hline Not working & $70(32.9)$ \\
\hline Any comorbidity other than hepatitis, (n, \%) & $78(35.6)$ \\
\hline Hypertension & $40(18.8)$ \\
\hline Diabetes mellitus & $23(10.8)$ \\
\hline Chronic pulmonary disease & $6(2.8)$ \\
\hline Coronary artery disease & $6(2.8)$ \\
\hline Solid organ malignancy & $3(1.4)$ \\
\hline Rheumatologic disease & $3(1.4)$ \\
\hline Hematological malignancy & $1(0.5)$ \\
\hline Solid organ transplantation & $1(0.5)$ \\
\hline Any medication, (n, \%) & $109(51.2)$ \\
\hline Chronic viral hepatitis B (n, \%) & $179(84)$ \\
\hline $\begin{array}{l}\text { Duration of disease, years-mean ( } \pm \text { standard } \\
\text { deviation) }\end{array}$ & $12.6(6.08)$ \\
\hline Family history (n, \%) & $89(49.7)$ \\
\hline Any antiviral treatment $(n, \%)$ & 57 (31.8) \\
\hline \multicolumn{2}{|l|}{ Treatment option (n, \%) } \\
\hline Tenofovir disoproxil fumarate & $40(22.3)$ \\
\hline Entecavir & $17(9.5)$ \\
\hline Chronic hepatitis C (n, \%) & $34(16)$ \\
\hline $\begin{array}{l}\text { Duration of disease, years-mean ( } \pm \text { standard } \\
\text { deviation) }\end{array}$ & $10.7(4.75)$ \\
\hline Ongoing antiviral treatment $(n, \%)$ & $0(0)$ \\
\hline
\end{tabular}

We examined the behavioral characteristics of hepatitis patients after COVID-19 pandemic (Table 4). All of the CVH patients except one have increased hand washing, using disinfectants and wearing face masks rates. A significant number of patients expressed themselves to pay attention to avoiding form crowded area, meetings and using public transport.

\section{Discussion}

The COVID-19 pandemic may cause additional psychological distress in the population (9). We learned from the past pandemics that approximately $35 \%$ of individuals experienced depressive or anxiety symptoms one month after SARS period (10). In our study, $24.9 \%$ of hepatitis patients were anxious for being at higher risk for COVID-19 due to hepatitis disease. Also these people who were anxious about COVID-19 have discontinued their further follow-up According to The European Association for The Study of the Liver and The European Society of Clinical Microbiology and Infectious Disease, CHV doesn't appear to increase the risk of a critical course of COVID-19 (6). Higher level of knowledge should be provided, but this awareness should not lead to anxiety, depression or panic. An increasing amount of information and concerns are impacting on global mental health, so people may be exposed to misleading information by some social media platforms. Since misinformation sources may cause incorrect perception, discourses that may cause anxiety should be avoided in critical pandemic periods. Similar situation was reported in Italy in inflammatory bowel disease patients. They were severely worried about COVID-19 infection and its impact on their medication, disease prognosis. Therefore, Italy adopted several strategies for these special group of patients in order to maintain the quality standard of care (11). Higher pleasure from the health information received is associated with lower psychological impact of the epidemic, the content of information provided should be based on evidence to prevent an adverse, stressful and anxious reactions (12).

COVID-19 pandemic poses an extremely challenge to healthcare systems in affected countries (6). As well as the international organizations, positions of local authorities, health and other ministries, disease control centers, universities and research centers have critical importance in different levels to control the

Table 2. Discontinuance of follow-up in hepatitis B and C patients $(\mathrm{n}=213)$

\begin{tabular}{|c|c|}
\hline Discontinuance of follow-up, $n(\%)$ & $89(41.8)$ \\
\hline Associated with COVID-19 & $75(35.2)$ \\
\hline Non-associated with COVID-19 & $14(6.6)$ \\
\hline \multicolumn{2}{|l|}{ Causes of follow-up disruption, n (\%) } \\
\hline "I am afraid of admission to hospital" & $45(21.1)$ \\
\hline $\begin{array}{l}\text { "I didn't admit to hospital because I couldn't } \\
\text { reach my doctor" }\end{array}$ & $19(8.9)$ \\
\hline $\begin{array}{l}\text { "I thought that it would not be a problem to } \\
\text { disrupt my follow-up" }\end{array}$ & $10(4.7)$ \\
\hline "Because of the curfew" & $5(2.3)$ \\
\hline $\begin{array}{l}\text { "I kept in touch with my doctor who } \\
\text { postponed my appointment" }\end{array}$ & $4(1.9)$ \\
\hline COVID-19: Coronavirus-2019 & \\
\hline
\end{tabular}




\begin{tabular}{|c|c|c|c|}
\hline Patients characteristics & $\begin{array}{l}\text { Patients with disruption in follow- } \\
\text { up }(n=75)\end{array}$ & $\begin{array}{l}\text { Patients without disruption in follow-up } \\
(n=138)\end{array}$ & $p$ \\
\hline Female & $35(46.7)$ & $46(33.3)$ & \multirow{2}{*}{0.056} \\
\hline Male & $40(53.3)$ & $92(66.7)$ & \\
\hline $31-40$ & $25(33.3)$ & $29(21)$ & \multirow{3}{*}{0.056} \\
\hline $41-50$ & $15(20)$ & $24(17.4)$ & \\
\hline$>50$ & $29(38.7)$ & $79(57.2)$ & \\
\hline \multicolumn{4}{|l|}{ Education level } \\
\hline High school & $20(26.7)$ & $29(21)$ & \multirow{2}{*}{0.684} \\
\hline University & $18(24)$ & $33(23.9)$ & \\
\hline Presence of any comorbidity & $27(36)$ & $51(37)$ & 0.890 \\
\hline \multicolumn{4}{|l|}{ Type of hepatitis disease } \\
\hline Hepatitis B patients & $68(90.7)$ & $111(80.4)$ & \multirow{2}{*}{0.051} \\
\hline Hepatitis C patients & $7(9.3)$ & $27(19.6)$ & \\
\hline $\begin{array}{l}\text { Duration of illness, years, median } \\
\text { (minimum-maximum) }\end{array}$ & $10(4-30)$ & $10(1-40)$ & 0.602 \\
\hline Anxiety of being at higher risk for COVID-19 & $28(37.3)$ & 25 (18.1) & 0.002 \\
\hline
\end{tabular}

Table 4. Change of behavioral characteristics of hepatitis patients after COVID-19 pandemic $(n=213)$

\begin{tabular}{|l|l|}
\hline Behavioral characteristic & $\mathbf{n}(\%)$ \\
\hline $\begin{array}{l}\text { Increase in hand washing, usage of } \\
\text { disinfectants and wearing a face mask }\end{array}$ & $212(99.5)$ \\
\hline Avoiding going to out unless it is necessary & $209(98.1)$ \\
\hline Staying away from crowded areas & $205(96.2)$ \\
\hline Avoiding from using the public transport & $193(90.5)$ \\
\hline $\begin{array}{l}\text { Staying away from meeting with relatives } \\
\text { and friends }\end{array}$ & $189(88.7)$ \\
\hline Not preferring to shop from the markets & $91(42.7)$ \\
\hline $\begin{array}{l}\text { Preferring to shop on the internet more } \\
\text { frequently }\end{array}$ & $33(15.5)$ \\
\hline Doing change in nutritional habits & $31(14.6)$ \\
\hline Using herbal supplements & $12(5.6)$ \\
\hline COVID-19: Coronavirus-2019 & \\
\hline
\end{tabular}

pandemic (13). Turkey implemented numerous control measures immediately at the beginning of COVID-19 pandemic for managing with COVID-19 infection (13). One of these control measures was that people who used drugs regularly for chronic illnesses, can be provided the medications without any prescriptions or medical reports (14). They could obtain the medications directly from the pharmacy based on last medical reports (14). In this way, risk groups movement and admission to hospitals due to nonemergency issues were restricted. Because healthcare settings are one of the most important areas for prevention and control of viral transmission (6).

In our study, only three patients had treatment disruption by means of these efficient implementations in healthcare system. Since the face-to face contact can increase dissemination of the virus, different technical solutions can be found to enable remote physician-patient interactions, for example using telemedicine, visits by phone, sending follow-up prescription by mail (6). Use of telemedicine has increased dramatically last years (15). Routine follow-up of chronic disease, management and information of mild patients disease, rapidly triage of patient to the the related clinics can be provided by telehealth (15). Pandemics cause emerging of new unique challenges to health care delivery (16). We should accept that pandemic is a part of our lives and similar or new pandemis may appear at any time in the future. To be prepared for pandemics, it is necessary to work for rapidly implementation of telemedicine into the healthcare system.

In our study, only female gender was found as a risk factor for anxiety in hepatitis patients during COVID-19 pandemic $(p=0.010)$. Similar result was reported by Qiu et al. (17) in a nationwide survey about psychological distress among Chinese people during COVID-19 outbreak. They founded that female participants had significantly higher psychological distress than males $(p<0.001)$ (17). In another study, female gender was found as a risk factor for a higher levels of stress, anxiety, and depression in COVID-19 
pandemic $(p<0.05)(12)$. These findings supported the previous epidemiological studies showing gender' effect on prevalence of depression (18). Socioeconomic or reporting bias can lead to emerging the gender differences in anxiety disorder, however, several studies suggest that fluctuating levels of estradiol and progesterone play an important role in these differences (19). For this reason, sociodemographic information is very important for healthcare authorities to identify for high risk groups and to act early intervention during pandemic (12).

The vast majority of $\mathrm{CVH}$ patients paid attention to prevention measures for COVID-19 infection like hand washing, wearing mask, not going crowded area etc. These results were in agreement with the report of Zhong et al. (20). These high proportion of consistence to prevention measures could be related with participants' good knowledge about COVID-19 infection transmission routes (20). $\mathrm{CVH}$ patients were less impressed by outbreak, since these people isolated oneself due to chronic illness. Likewise, patients having different types of immunodeficiency switched to remote assistance program in Italy (21). It was showed that the remote assistance program didn't have negative impact on health-related quality of life of these patients (21).

\section{Study Limitations}

A number of limitations of this study should be noted. First, the size of sample was small. Second, the study included only of $\mathrm{CVH}$ patients who were followed-up in single center. Further studies with large multi-center samples are needed.

\section{Conclusion}

This study intended to examine the impact of the COVID-19 pandemic on treatment, follow-up and behavioral characteristics of chronic hepatitis patients. Despite we investigated the impact of COVID-19 infection in a limited number of hepatitis patients, we can say that CVH patients' awareness about COVID-19 and application of control measures were well enough. We detected anxiety as the only factor causing follow-up interruption. Informing patients in a way not to cause anxiety is very important to prevent any disruption in the follow up- and treatment of the primary disease. By means of efficient implementations in healthcare system, continuity of treatment can be provided in patients with chronic illness during crisis period like COVID-19 pandemic.

\section{Acknowledgement}

We would like to thank Gülşen Karaca, Müberra Erkaya, Alican Ulaş for contribution to our study.

\section{Ethics}

Ethics Committee Approval: The study protocol and procedures of informed consent were approved by Ankara City Hospital Ethical Committee (approval number: E1/724/2020, date: 04/06/2020)

Informed Consent: It was obtained.

Peer-review: Externally peer-reviewed.

\section{Authorship Contributions}

Concept: R.G., B.K., Design: R.G., B.K., E.M.S., Data Collection or Processing: B.K., E.M.S., Analysis or Interpretation: R.G., B.K.,
E.M.S., Literature Search: R.G., B.K., E.M.S., Writing: R.G., B.K. E.M.S.

Conflict of Interest: The authors declare no conflict of interest. Financial Disclosure: The authors declare that this study has not received any financial support.

\section{References}

1. Zhang Y, Ma ZF. Impact of the COVID-19 pandemic on mental health and quality of life among local residents in Liaoning Province, China: A cross-sectional study. International journal of environmental research and public health. 2020;17:2381.

2. Fu J, Kong J, Wang W, Wu M, Yao L, Wang Z, Jin J, Wun D, Yu X. The clinical implication of dynamic neutrophil to lymphocyte ratio and D-dimer in COVID-19: A retrospective study in Suzhou China. Thrombosis Research. 2020;192:3-8

3. Cucinotta D, Vanelli M. WHO Declares COVID-19 a Pandemic Acta Biomed. 2020;91:157-160.

4. Demirbilek Y, Pehlivantürk G, Özgüler ZÖ, Alp Meşe E. COVID-19 outbreak control, example of ministry of health of Turkey. Turk J Med Sci. 2020;50(Si-1):489-494

5. T.C. BS. COVID-19 (SARS-CoV-2 ENFEKSIYONU) (Bilim Kurulu Çalışması) Genel Bilgiler, Epidemiyoloji ve Tanı: T.C. SAĞLIK BAKANLIĞI; 2020 [updated 01.06.2020. Available from: https:// covid19bilgi.saglik.gov.tr/depo/rehberler/covid-19-rehberi/COVID19_REHBERI_GENEL_BILGILER_EPIDEMIYOLOJI_VE_TANI.pdf.

6. Boettler T, Newsome PN, Mondelli MU, Maticic M, Cordero E, Cornberg M, Berg T. Care of patients with liver disease during the COVID-19 pandemic: EASL-ESCMID position paper. JHEP Rep. 2020;2:100113.

7. Guan WJ, Ni ZY, Hu Y, Liang WH, Ou CQ, He JX, Liu L, Shan H, Lei C, Hui DSC, Du B, Li L,. Zeng G, Yuen KY, Chen R, Tang C, Wang T, Chen P, Xiang J, Li S, Wang J, Liang Z, Peng Y, Wei L, Liu Y, Hu Y, Peng P, Wang J, Liu J, Chen Z, Li G, Zheng Z, Qiu S, Luo J, Ye C, Zhu S, Zhong N. Clinical Characteristics of Coronavirus Disease 2019 in China. N Engl J Med. 2020;382:1708-1720.

8. $\quad$ Qi X, Wang J, Li X, Wang Z, Liu Y, Yang H, Xiaodan L, Shi J, Xiang H, Liu T, Kawada N, Maruyama H, Jiang Z, Wang F, Takehara T, Rockey DC, Sarin SK; COVID-Cirrhosis-CHESS Group. Clinical course of COVID-19 in patients with pre-existing decompensated cirrhosis: initial report from China. Hepatol Int. 2020:1-5

9. Sockalingam S, Leung SE, Cassin SE. The Impact of COVID-19 on Bariatric Surgery: Re-Defining Psychosocial Care. Obesity. 2020

10. Cheng SK, Wong C, Tsang J, Wong K. Psychological distress and negative appraisals in survivors of severe acute respiratory syndrome (SARS). Psychol Med. 2004;34:1187-1195.

11. Fiorino G, Allocca M, Furfaro F, Gilardi D, Zilli A, Radice S, Spinelli A, Danese S. Inflammatory bowel disease care in the COVID-19 pandemic era: the Humanitas, Milan, experience. J Crohns Colitis. 2020.

12. Wang $C$, Pan $R$, Wan $X$, Tan $Y, X u$ L, Ho CS, Ho RC. Immediate psychological responses and associated factors during the initial stage of the 2019 coronavirus disease (COVID-19) epidemic among the general population in China. Int J Environ Res Public Health. 2020;17:1729.

13. Tufan ZK, Kayaaslan B. Crushing the curve, the role of national and international institutions and policy makers in COVID-19 pandemic. Turk J Med Sci. 2020;50:495-508.

14. COVID-19 Tedbiri: Kronik Hastalıklarda Sona Eren Sağlık Raprolarıl Geçerli: Aile, Çalışma ve Sosyal Hizmetler Bakanlığı; 2020 [Available from: https://www.ailevecalisma.gov.tr/tr-tr/haberler/ 
bakan-selcuk-kronik-hastaligi-bulunan-sigortalilarimizin-saglikraporlari-ve-receteleri-ikinci-bir-duyuraya-kadar-gecerli-sayilacak/.

15. Lurie N, Carr BG. The Role of Telehealth in the Medical Response to Disasters. JAMA Intern Med. 2018;178:745-746.

16. Hollander JE, Carr BG. Virtually Perfect? Telemedicine for Covid19. N Engl J Med. 2020;382:1679-1681.

17. Qiu J, Shen B, Zhao M, Wang Z, Xie B, Xu Y. A nationwide survey of psychological distress among Chinese people in the COVID19 epidemic: implications and policy recommendations. Gen Psychiatr. 2020;33:e100213.

18. Lim GY, Tam WW, Lu Y, Ho CS, Zhang MW, Ho RC. Prevalence of Depression in the Community from 30 Countries between 1994 and 2014. Sci Rep. 2018;8:2861.
19. Li SH, Graham BM. Why are women so vulnerable to anxiety, trauma-related and stress-related disorders? The potential role of sex hormones. Lancet Psychiatry. 2017;4:73-82.

20. Zhong BL, Luo W, Li HM, Zhang QQ, Liu XG, Li WT, Li Y. Knowledge, attitudes, and practices towards COVID-19 among Chinese residents during the rapid rise period of the COVID-19 outbreak: a quick online cross-sectional survey. Int J Biol Sci. 2020;16:1745-1752

21. Pulvirenti F, Cinetto F, Milito C, Bonanni L, Pesce AM, Leodori G, Garzi G, Mglionico M, Taboll, S, Quinti I. Health-Related-Quality of Life in Common Variable Immunodeficiency Italian patients switched to remote assistance during the COVID-19 pandemic. J Allergy Clin Immunol Pract. 2020;8:1894-1899. 